\begin{abstract}
Iranica
Abstracta Iranica Revue bibliographique pour le domaine irano-aryen

Volume 32-33 | 2013

Comptes rendus des publications de 2009-2010
\end{abstract}

\title{
Laurianne Martinez-Sève. Suse et les Séleucides au IIIe siècle avant J.-C.
}

\section{Rémy Boucharlat}

\section{(2) OpenEdition}

1 Journals

\section{Édition électronique}

URL : http://journals.openedition.org/abstractairanica/40551

DOI : 10.4000/abstractairanica.40551

ISSN : 1961-960X

Éditeur :

CNRS (UMR 7528 Mondes iraniens et indiens), Éditions de l'IFRI

\section{Édition imprimée}

Date de publication : 1 décembre 2013

ISSN : 0240-8910

\section{Référence électronique}

Rémy Boucharlat, « Laurianne Martinez-Sève. Suse et les Séleucides au IIle siècle avant J.-C. 》, Abstracta Iranica [En ligne], Volume 32-33 | 2013, document 185, mis en ligne le 01 juillet 2016, consulté le 05 octobre 2020. URL : http://journals.openedition.org/abstractairanica/40551 ; DOI : https://doi.org/ $10.4000 / a b s t r a c t a i r a n i c a .40551$

Ce document a été généré automatiquement le 5 octobre 2020.

Tous droits réservés 


\title{
Laurianne Martinez-Sève. Suse et les Séleucides au IIIe siècle avant J.-C.
}

\author{
Rémy Boucharlat
}

\section{RÉFÉRENCE}

Laurianne Martinez-Sève. "Suse et les Séleucides au IIIe siècle avant J.-C. ", in : Edward DĄbrowa, ed., New Studies on the Seleucids. Kraków, Jagiellonian University Press, 2010, p. 41-66. (Electrum 18)

1 L'A. revient sur Suse au III ${ }^{\mathrm{e}}$ s., sujet qu'elle avait abordé principalement par les données archéologiques (Revue Archéologique 2002). Cette fois, les données numismatiques sont privilégiées pour montrer l'activité de Suse à cette époque. L'importance de l'atelier monétaire à la fin du $4^{\mathrm{e}} \mathrm{s}$. s'expliquerait si Suse était la base d'une forme de reconquête du Fars. Cette activité est faible ensuite entre Antiochos I et Seleucos III. La refondation sous le nom de Séleucie de l'Eulaios, achevée sous Antiochos III, est parfois attribuée à Séleucos I. L'A. suggère Seleucos II, dont le rôle est aujourd'hui réévalué par la nouvelle datation de l'inscription d'Ikaros (Failaka, Koweit). Mais l'ensemble des données disponibles ne nous donne que peu d'information sur la population de Suse qui apparaît relativement réduite.

\section{AUTEURS}

RÉMY BOUCHARLAT

CNRS, Lyon 